\title{
Screening Ornamentals for Their Potential as As Accumulator Plants
}

\author{
Stewart T. Reed ${ }^{1}$, Tomas Ayala-Silva ${ }^{1}$, Christopher B. Dunn ${ }^{1}$, Garry G. Gordon ${ }^{2} \&$ Alan Meerow ${ }^{1}$ \\ ${ }^{1}$ USDA, Agricultural Research Service, Subtropical Horticulture Research Station, 13601 Old Cutler Road, \\ Miami, FL 33158, USA \\ ${ }^{2}$ Department of Homeland Security, U.S. Customs and Border Protection, Miami Cargo Clearance Center, 6601 \\ NW $25^{\mathrm{TH}}$ Street Room 272, Miami, FL 33122, USA \\ Correspondence: Stewart T. Reed, USDA, Agricultural Research Service, Subtropical Horticulture Research \\ Station, 13601 Old Cutler Road, Miami, FL 33158, USA. Tel: 1-786-573-7048. E-mail: \\ stewart.reed@ars.usda.gov
}

Received: August 12, 2013 Accepted: August 28, 2013 Online Published: September 15, 2013

doi:10.5539/jas.v5n10p20 URL: http://dx.doi.org/10.5539/jas.v5n10p20

\begin{abstract}
Arsenic-based pesticides, herbicides and insecticides are used in horticultural operations resulting in soil contamination around greenhouse structures. Phytoremediation and phytostabilization are two techniques for treating arsenic (As) contaminated soil. Several ornamental plant species, Iris (Iris savannarum), switchgrass (Panicum virgatum), Tithonia rotundiflora, Coreopsis lanceolata, sunflower (Helianthus annuus), and marigold (Tagetes erecta), were evaluated for their potential use as accumulator plants. Based on dry weight, tithonia and coreopsis were most sensitive to As. Tithonia had an $85 \%$ reduction in dry weight at $0.75 \mathrm{mg} \mathrm{As} \mathrm{L}^{-1}$ and

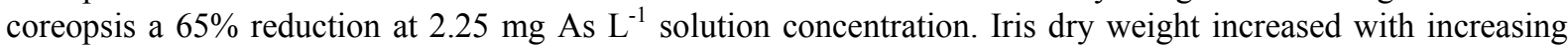
solution concentrations but As did not accumulate in tissue. At the high As rate, marigold and sunflower had uptake ratios of 7.4 and 16.6, respectively, and translocation factors near one. Both show little effect of As toxicity on dry weights production, therefore, are appealing candidates for phytoremediation and phytostabilization. Switchgrass and iris can be harvested multiple times a year, making them candidates for phytostabilization.
\end{abstract}

Keywords: arsenic, iris, marigold, sunflower, switchgrass, translocation factor, uptake ratio

Abbreviations Translocation factor: $\mathrm{TF}=$ shoot As / root As in $\mathrm{mg} \mathrm{As} \mathrm{kg}^{-1}$ plant dry weight; uptake ratio: $\mathrm{UR}=$ $\mathrm{mg} \mathrm{As} \mathrm{kg}{ }^{-1}$ plant dry weight/ solution As concentration in $\mathrm{mg} \mathrm{L}^{-1}$

\section{Introduction}

Arsenic is a metalloid that can accumulate in soil as a result of mining and industrial activities; application of As based herbicides, insecticides, rodenticides and wood preservatives; and irrigation with water contaminated with As (Zhao, Ma, Meharg, \& McGrath, 2009). Naturally occurring soil As can range from 1-40 mg As kg-1 soil (Walsh, Sumner, \& Keeney, 1977), however, contaminated levels can reach as high as $2600 \mathrm{mg} \mathrm{As} \mathrm{kg}{ }^{-1}$ soil (Meharg, Naylor, \& Macnair, 1994). In horticultural crop production systems, arsenic-based pesticides, herbicides and insecticides have led to considerable contamination on turf, orchards, and around greenhouses, shadehouses and other structures (Woolson, Axley, \& Kearney, 1971; Murphy \& Aucott, 1998).

Arsenic is not essential for plants (Marin, Masscheleyn, \& Patrick, 1992) and has no known metabolic function. Plant species vary in their ability to tolerate As (Meharg, 1994) with toxicity threshold levels ranging from 5 to $100 \mathrm{mg} \mathrm{As} \mathrm{kg}^{-1}$ dry weight for most plants (Kabata-Pendias \& Pendias, 1992).

Brake fern (Pteris vittata) found growing on an As contaminated site in Florida was the first arsenic hyperaccumulator described in the literature (Ma et al., 2001). Ma reported that brake fern fronds growing in $1500 \mathrm{mg} \mathrm{kg}^{-1}$ As contaminated soil accumulated up to $15861 \mathrm{ug} \mathrm{As} \mathrm{g}^{-1}$ plant dry weight over a two week growing period. Since that time several other fern species have been identified as As-hyperaccumulators: Pteris cretica, Pteris longifolia, P. vittata, Pteris umbrosa (Zhao, Dunham, \& McGrath, 2002) and Pityrogramma calamelanos (Visoottiviseth, Francesconi, \& Sridokchan, 2002). However, not all ferns have the ability to hyperaccumulate As. Meharg (2003) reported that Pteris straminea and Pteris tremula did not hyperaccumulate As in their fronds. Plants that accumulate As translocate a large portion of it to their shoot. The As hyperaccumulator $P$. vittata shipped $8 \times$ more As from root to shoot than the nonhyperaccumulator $P$. tremula (Caille, Zhao, \& McGrath, 
2005) and $2.8 \mathrm{x}$ more than Pteris ensiformis (Singh \& Ma, 2006).

Several investigators have identified a variety of species other than ferns that hyperaccumulate or are tolerant to high levels of soil As. Ansari et al. (2013) screened ten Indian mustard (Brassica juncea L.) genotypes an reported that at 50 um As, mustard shoots contained from 1.84 to $3.65 \mathrm{mg} \mathrm{As} \mathrm{g}^{-1}$ dry weight. As accumulation was reported in Chilopsis linearis (desert willow) by Castillo-Michel et al. (2009), in the flowering plant Cytisus striatus by Bleeker, Schat, Vooijs, Verkleij, and Ernst (2003), and in Isatis capadocica, a brassica, by Karimi, Ghaderian, Raab, Feldmann, and Meharg (2009).

Phytoremediation employs plants to remove toxic substances from the soil. An ideal candidate for phytoremediation would have vigorous growth to help prevent transportation of the substance off site by erosion. The plant should accumulate the toxic substance in large amounts and sequester it in easily harvestable plant parts. Plants defined as As hyperaccumulators have a Bioaccumulation Factor (BF) $>1000$ ug As g ${ }^{-1}$ plant dry weight (Machado-Estrada, Calderón, Moreno-Sánchez, \& Rodríguez-Zavala, 2012). They have a shoot-to-root As concentration ratio (Translocation Factor (TF)) higher than 1 . However, plants with a BF $>1$ can be useful in phytoremediation (McGrath \& Zhao, 2003), especially if they have a TF $>1$. Ornamental plants generally, have not been investigated as a potential source for phytoremediation and stabilization. Ornamentals can provide a marketable commodity, for example cut flowers, to somewhat offset the cost of land taken out of production. In addition, these plants can provide an aesthetic quality to buildings located on contaminated sites. The purpose of this study was to screen several ornamentals for their potential use as As accumulator plants.

\section{Materials and Methods}

\subsection{Plant Species}

Six plant species were used in this study: Iris (Iris savannarum), switchgrass (Panicum virgatum), Tithonia rotundiflora, Coreopsis lanceolata, sunflower (Helianthus annuus), and marigold (Tagetes erecta). Iris rhizomes, approximately $10 \mathrm{~cm}$ in length were collected from a single clonal plant. To stabilize rhizomes until a root system began to develop, iris plants were set in rockwool. All other species were planted in a $25 \%$ perlite, $37 \%$ pine bark, $8 \%$ sand, $30 \%$ coir potting mixture. Switchgrass seed was evenly sowed in $28 \times 53 \mathrm{~cm}$ trays. Once plants reached $10 \mathrm{~cm}$ in height, $3018-\mathrm{cm}$ sections of turf were cutout and placed into 26-cm diameter pots $(3.8$ L). Switchgrass was trimmed to a uniform $15 \mathrm{~cm}$ height before initiation of treatments. Tithonia, coreopsis, sunflower and marigold were planted four seeds to a pot and thinned to one plant per pot shortly after emergence. The study was conducted over three different time periods with two plant species growing during each period. Dates for each time period are given in Table 1. Tithonia, sunflower and marigold had at least two fully developed leaves before pots were attached to a hydroponic system. Iris, switchgrass and coreopsis were at least $10 \mathrm{~cm}$ tall and iris and coreopsis had $\geq 3$ leaves when hydroponic systems were activated.

Table 1. Planting, initiation of arsenic treatments and harvest dates for six plant species: Iris (Iris savannarum), switchgrass (Panicum virgatum), Tithonia rotundiflora, Coreopsis lanceolata, sunflower (Helianthus annuus) and Marigold marigold (Tagetes erecta)

\begin{tabular}{llll}
\hline Species & Planting & Treatment & Harvest \\
\hline Iris (Iris savannarum) & 21-Dec-09 & 10-Mar-10 & 13-May-10 \\
Switchgrass (Panicum virgatum) & 21-Dec-09 & 10-Mar-10 & 13-May-10 \\
Tithonia rotundiflora & 6-Oct-10 & 20-Oct-10 & 16-Nov-10 \\
Coreopsis lanceolata & 6-Oct-10 & 20-Oct-10 & 23-Nov-10 \\
Sunflower (Helianthus annuus) & 1-Feb-11 & 16-Feb-11 & 22-Mar-11 \\
Marigold (Tagetes erecta) & 1-Feb-11 & 16-Feb-11 & 22-Mar-11 \\
\hline
\end{tabular}

\subsection{Hydroponic System}

Six ebb-and-flow type hydroponic plant maintenance systems were setup. Each system contained a $132 \mathrm{~L}$ reservoir tank connected to $12,3.8-\mathrm{L}$ pots. A timer allowed the system to cycle between $30 \mathrm{~min}$. wet and $4 \mathrm{hr}$. drain periods, beginning at 8:00 A.M., ending at 4:00 P.M. followed by a $12 \mathrm{hr}$. drain period. Each $132 \mathrm{~L}$ tank contained a modified Hoagland solution with $2.0 \mathrm{mM} \mathrm{Ca}\left(\mathrm{NO}_{3}\right)_{2}, 3 \mathrm{mM} \mathrm{KNO}_{3}, 1.0 \mathrm{mM} \mathrm{MgSO} 4,0.25 \mathrm{mM}$ $\mathrm{Ca}\left(\mathrm{H}_{2} \mathrm{PO}_{4}\right)_{2}, 12.5 \mathrm{uM} \mathrm{H}_{3} \mathrm{BO}_{3}, 1.0 \mathrm{uM} \mathrm{MnSO}_{4}, 1.0 \mathrm{uM} \mathrm{ZnSO}{ }_{4}, 0.25 \mathrm{uM} \mathrm{CuSO}_{4}, 0.2 \mathrm{uM}\left(\mathrm{NH}_{4}\right)_{6} \mathrm{Mo}_{7} \mathrm{O}_{24}$, and 10 
uM Fe-EDDHA. Tap water used to mix nutrient solutions averaged $0.0028 \mathrm{mg} \mathrm{L}^{-1}$ As $(0.448 \mathrm{mg}$ per reservoir tank). Plants were allowed to acclimate to hydroponic feeding for a minimum of one week before beginning As treatments. Enough $\mathrm{Na}_{2} \mathrm{HAsO}_{4}$ was added to different reservoirs to make 0, 10, 20, 30, 40, 50 or $70 \mathrm{uM}$ As as a final solution concentration. Iris, switchgrass, sunflower and marigold were grown in $0,10,20,40,50$ or $70 \mathrm{uM}$ As $\left(0.0,0.75,1.5,3.0,3.75,5.25 \mathrm{mg} \mathrm{L}^{-1}\right.$ As, respectively) while coreopsis and tithonia were grown in $0,10,30$, 50 , or $70 \mathrm{uM}$ As. Reservoir $\mathrm{pH}$ was adjusted daily to $\mathrm{pH} 6.5$ with either $\mathrm{NaOH}$ or $\mathrm{H}_{2} \mathrm{SO}_{4}$. Nutrient and $\mathrm{As}$ solutions were replaced weekly. Arsenic waste water was collected, filtered to remove As, and filters properly disposed of as a hazardous waste. Plants were maintained in hydroponic solution until flowering, 40 to 121 days depending on the species. A portion of iris rhizome from the 0.0 and 5.25 As treatments were maintained in 0.0 and $133 \mathrm{uM}\left(10 \mathrm{mg} \mathrm{L}^{-1}\right)$ As solution, respectively, for 366 days before plants flowered.

\subsection{Sampling}

Plant height was measured from the soil surface along the main stem to the upper most node for tithonia, sunflower and marigold or with coreopsis to the uppermost point when leaves were held upright. For iris the combined length of each leaf substituted for plant height. Prior to initial As treatment switchgrass was clipped to $10 \mathrm{~cm}$ height. Canopy height was measured at 76,91 and 121 days and following each measurement the canopy was clipped back to a $15 \mathrm{~cm}$ height. Plant growth was calculated as height at harvest (accumulated height for switchgrass) minus initial height. Prior to applying treatments, and again at harvest the number of leaves was recorded for all species except switchgrass. The initial leaf number was subtracted from the final count to determine new leaf growth. Shoot and root tissue were harvested separately, oven dried at $45^{\circ} \mathrm{C}$ until there was no longer a weight change with additional drying and the dry weights recorded. Dried tissue was stored for analysis. An uptake ratio

$$
\mathrm{UR}=\mathrm{mg} \mathrm{As} \mathrm{kg}^{-1} \text { plant dry weight/ solution As concentration in } \mathrm{mg} \mathrm{L}^{-1}
$$

and translocation factor

$$
\mathrm{TF}=\text { shoot As } / \text { root As in mg As kg-1 plant dry weight }
$$

were calculated for each species and each treatment.

\subsection{Sample Analysis}

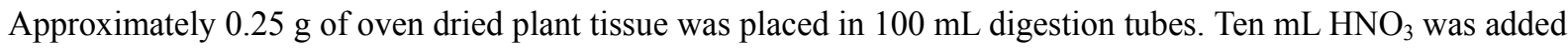
and samples digested in a Start D microwave digestion system (Milestone Inc., Shelton, Connecticut) for 15 min to reach $200^{\circ} \mathrm{C}$ then kept at this temperature for an additional $15 \mathrm{~min}$. Digests were diluted to $100 \mathrm{~mL}$ and stored at $4{ }^{\circ} \mathrm{C}$ prior to analysis. Arsenic concentration was determined by inductively coupled plasma - optical emission spectrometry with an iCAP 6300 Duo View (ThermoFisher Scientific, West Palm Beach, Florida). Data were analyzed and concentrations determined using ThermoFisher Scientific iCAP 6300 iTEVA software. Arsenic was determined at the most intense atomic emission.

\subsection{Statistical Analysis}

Each plant species was analyzed separately. The data represent means calculated from six replicated pots for each As treatment. Analysis of variance was preformed using the Proc Mixed procedure of Statistical Analysis System (SAS Inst., 1999). Tukey adjusted lsmeans were used for comparison at $\mathrm{P}<0.05$ unless stated otherwise. Arithmetic means were used to calculate uptake ratio and translocation factor.

\section{Results}

\subsection{General Comments}

Statistical analysis revealed significant differences in As concentration at $P \geq 0.05$ between treatments for all plants species used in this study. Significant differences in As concentration at $P \geq 0.05$ also were found between root and shoot tissue for all species. An increase in solution As lead to an increase in As tissue concentration, however, this was not the case with iris leaf and flower tissues. There were no differences for As between treatments. Iris and marigold dry weights tended to increase with increasing solution As up to $5.25 \mathrm{mg} \mathrm{L}^{-1}$. In Panicum virgatum As uptake increased with successive harvests (data not shown).

\subsection{Plant Physical Characteristics}

Compared to the control, significant treatment dry weight differences in root and shoot tissue for coreopsis and tithonia first appeared at 2.25 and $0.75 \mathrm{mg} \mathrm{L}^{-1}$ solution As concentration, respectively (Table 2). At $5.25 \mathrm{mg} \mathrm{L}^{-1}$ coreopsis had an $84 \%$ reduction in total plant dry weight producing 29 fewer leaves and $15 \mathrm{~cm}$ less growth than the $0.0 \mathrm{mg} \mathrm{As} \mathrm{L}{ }^{-1}$ control. The overall inhibition of growth seen in coreopsis was even more striking in tithonia. 
At $5.25 \mathrm{mg} \mathrm{As} \mathrm{L}^{-1}$ there was a $98 \%$ reduction in dry weight, virtually no new leaves produced and $30 \mathrm{~cm}$ less growth than the control. Coreopsis and tithonia had URs $>20$ and a TF of 0.07 and 1.13, respectively.

Table 2. Selected physical characteristics, uptake ratio (UR) and Translocation Factor (TF) of plants grown in varying As solution concentrations

\begin{tabular}{|c|c|c|c|c|c|c|}
\hline $\begin{array}{l}\text { Solution } \\
\text { concentration } \\
(\mathrm{ppm})\end{array}$ & $\begin{array}{l}\text { Root dry } \\
\text { wt (g) }\end{array}$ & $\begin{array}{l}\text { shoot dry } \\
\text { wt (g) }\end{array}$ & $\begin{array}{l}\text { New leaf } \\
\text { growth }\end{array}$ & $\begin{array}{l}\text { Plant } \\
\text { growth } \\
(\mathrm{cm})\end{array}$ & UR & $\mathrm{TF}$ \\
\hline & \multicolumn{6}{|c|}{ Coreopsis lanceolata } \\
\hline 0.00 & $1.97 \mathrm{a}^{\dagger}$ & $4.96 \mathrm{a}$ & $43.8 \mathrm{ab}$ & $20.4 \mathrm{a}$ & $0.0 \mathrm{c}$ & $0.44 \mathrm{a}$ \\
\hline 0.75 & $1.64 \mathrm{ab}$ & $3.91 \mathrm{ab}$ & $48.5 \mathrm{a}$ & $13.9 \mathrm{ab}$ & $85.4 \mathrm{a}$ & $0.17 \mathrm{~b}$ \\
\hline 2.25 & $0.70 \mathrm{bc}$ & $1.75 \mathrm{bc}$ & $27.3 \mathrm{abc}$ & $11.0 \mathrm{~b}$ & 79.9 a & $0.16 \mathrm{~b}$ \\
\hline 3.75 & $0.48 \mathrm{c}$ & $1.39 \mathrm{c}$ & $24.8 \mathrm{bc}$ & $8.8 \mathrm{~b}$ & $52.5 \mathrm{~b}$ & $0.13 \mathrm{~b}$ \\
\hline \multirow[t]{2}{*}{5.25} & $0.44 \mathrm{c}$ & $0.69 \mathrm{c}$ & $15.0 \mathrm{c}$ & $5.5 \mathrm{~b}$ & $73.0 \mathrm{ab}$ & $0.07 \mathrm{~b}$ \\
\hline & \multicolumn{6}{|c|}{ Tithonia rotundiflora } \\
\hline 0.00 & $16.19 \mathrm{a}$ & $26.72 \mathrm{a}$ & $101.8 \mathrm{a}$ & $36.8 \mathrm{a}$ & $0.0 \mathrm{c}$ & $0.00 \mathrm{~b}$ \\
\hline 0.75 & $3.44 \mathrm{~b}$ & $4.10 \mathrm{~b}$ & $33.8 \mathrm{~b}$ & $16.3 \mathrm{~b}$ & $102.3 \mathrm{a}$ & $1.27 \mathrm{ab}$ \\
\hline 2.25 & $1.27 \mathrm{~b}$ & $1.55 \mathrm{~b}$ & $9.8 \mathrm{c}$ & $10.3 \mathrm{bc}$ & $47.3 \mathrm{~b}$ & $2.38 \mathrm{a}$ \\
\hline 3.75 & $2.01 \mathrm{~b}$ & $1.31 \mathrm{~b}$ & $8.1 \mathrm{c}$ & $7.0 \mathrm{c}$ & $20.2 \mathrm{c}$ & $1.06 \mathrm{ab}$ \\
\hline \multirow[t]{2}{*}{5.25} & $0.61 \mathrm{~b}$ & $0.46 \mathrm{~b}$ & $-0.5 c$ & $6.2 \mathrm{c}$ & $33.4 \mathrm{bc}$ & $1.13 \mathrm{ab}$ \\
\hline & \multicolumn{6}{|c|}{ Iris savannarum } \\
\hline 0.00 & $0.75 \mathrm{ab}$ & $2.29 \mathrm{ab}$ & 29.0 & 1467.2 & $0.0 \mathrm{~b}$ & $2.93 \mathrm{a}$ \\
\hline 0.75 & $0.42 \mathrm{~b}$ & $1.15 \mathrm{~b}$ & 28.3 & 1354.8 & $5.0 \mathrm{ab}$ & $1.23 \mathrm{a}$ \\
\hline 1.50 & $0.41 \mathrm{~b}$ & $1.10 \mathrm{~b}$ & 20.7 & 874.7 & $5.9 \mathrm{ab}$ & $0.82 \mathrm{a}$ \\
\hline 3.00 & $1.40 \mathrm{a}$ & $3.95 \mathrm{ab}$ & 28.5 & 1703.4 & $5.5 \mathrm{ab}$ & $0.63 \mathrm{a}$ \\
\hline 3.75 & $1.06 \mathrm{ab}$ & $3.69 \mathrm{ab}$ & 24.8 & 1333.0 & $3.3 \mathrm{ab}$ & $1.54 \mathrm{a}$ \\
\hline \multirow{2}{*}{5.25} & $1.62 \mathrm{a}$ & $5.31 \mathrm{a}$ & 17.3 & 1060.1 & $6.7 \mathrm{a}$ & $9.21 \mathrm{a}$ \\
\hline & \multicolumn{6}{|c|}{ Tagetes erecta } \\
\hline 0.00 & 15.91 & 54.12 & $58.3 \mathrm{~b}^{\dagger \dagger}$ & 59.9 & $0.0 \mathrm{c}$ & $0.23 \mathrm{a}$ \\
\hline 0.75 & 13.42 & 65.13 & $59.0 \mathrm{~b}$ & 61.3 & $20.3 \mathrm{a}$ & $0.50 \mathrm{a}$ \\
\hline 3.00 & 16.45 & 58.31 & $74.0 \mathrm{ab}$ & 59.2 & $7.3 \mathrm{bc}$ & $0.34 \mathrm{a}$ \\
\hline 3.75 & 13.60 & 59.05 & $65.7 \mathrm{ab}$ & 52.9 & $10.6 \mathrm{~b}$ & $0.27 \mathrm{a}$ \\
\hline \multirow[t]{2}{*}{5.25} & 14.58 & 68.13 & $81.3 \mathrm{a}$ & 63.4 & $7.4 \mathrm{bc}$ & $1.20 \mathrm{a}$ \\
\hline & \multicolumn{6}{|c|}{ Helianthus annuus } \\
\hline 0.00 & 2.55 & 16.75 & $16.2 \mathrm{~b}$ & 16.4 & $0.0 \mathrm{c}$ & $0.89 \mathrm{a}$ \\
\hline 0.75 & 2.10 & 14.57 & $20.8 \mathrm{ab}$ & 15.2 & $32.1 \mathrm{a}$ & $0.84 \mathrm{a}$ \\
\hline 3.00 & 2.47 & 17.23 & $23.0 \mathrm{a}$ & 18.2 & $25.7 \mathrm{ab}$ & $1.23 \mathrm{a}$ \\
\hline 3.75 & 1.60 & 14.18 & $24.8 \mathrm{a}$ & 15.6 & $18.1 \mathrm{~b}$ & $0.84 \mathrm{a}$ \\
\hline \multirow[t]{2}{*}{5.25} & 1.98 & 12.89 & $21.2 \mathrm{ab}$ & 16.2 & $16.6 \mathrm{~b}$ & $0.88 \mathrm{a}$ \\
\hline & \multicolumn{6}{|c|}{ Panicum virgatum } \\
\hline 0.00 & $39.55 \mathrm{a}$ & $71.54 \mathrm{a}$ & - & $79.1 \mathrm{a}$ & $0.0 \mathrm{~b}$ & $0.20 \mathrm{~b}$ \\
\hline 0.75 & $37.03 \mathrm{ab}$ & $44.74 \mathrm{bc}$ & - & $59.5 \mathrm{c}$ & $3.5 \mathrm{a}$ & $0.24 \mathrm{~b}$ \\
\hline 1.50 & $36.74 \mathrm{ab}$ & $57.26 \mathrm{ab}$ & - & $69.3 \mathrm{~b}$ & $2.7 \mathrm{a}$ & $0.10 \mathrm{~b}$ \\
\hline 3.00 & $29.45 \mathrm{~b}$ & $30.24 \mathrm{~cd}$ & - & $55.8 \mathrm{~cd}$ & $1.8 \mathrm{ab}$ & $0.56 \mathrm{~b}$ \\
\hline 3.75 & $43.05 \mathrm{a}$ & $46.73 \mathrm{bc}$ & - & $69.7 \mathrm{~b}$ & $2.5 \mathrm{a}$ & $1.65 \mathrm{a}$ \\
\hline 5.25 & $28.16 \mathrm{~b}$ & $22.16 \mathrm{~d}$ & - & $49.8 \mathrm{~d}$ & $1.5 \mathrm{~b}$ & $0.16 b$ \\
\hline
\end{tabular}

$\dagger$ means followed by the same letter are statistically similar at $P \geq 0.05$.

$\dagger^{\dagger}$ Lsmeans estimates not adjusted by Tukey's. 
Marigold and sunflower had no significant differences in root and shoot dry weights and plant growth between treatments (Table 2). Averaged across As treatments, the UR for marigold was 11.4 and the TF 0.5. The UR in sunflower declined slightly with increasing As solution. Averaged across treatments the UR and TF were 23.1 and 0.9 , respectively.

Iris root and shoot dry weights increased with increasing solution concentrations above $3.00 \mathrm{mg} \mathrm{As} \mathrm{L}^{-1}$ (Table 2). Although not significantly different, total dry weight from the $5.25 \mathrm{mg} \mathrm{L}^{-1}$ treatment was $\geq 2 \mathrm{x}$ that found in the control. Although there were no differences in the number of new leaves developed and total leaf length between the control and all As treatments, with the $5.25 \mathrm{mg} \mathrm{L}^{-1}$ treatment 12 fewer new leaves were produced, and the new leaves that were produced were longer than new leaves produced by the control. An increase in solution As led to an increase in individual leaf lengths (data not shown). Iris produced a 5.3 average UR that varied little with increases in solution As concentration. There were no significant differences in iris $\mathrm{TF}$, although the values varied from 0.82 to 9.21. High TF values tended to occur in plants that produced a large number of leaves.

Switchgrass control had significantly greater root dry weight than that found in 3.0 and $5.25 \mathrm{mg} \mathrm{L}^{-1}$ As treatments and greater total shoot dry weight than all but the $1.5 \mathrm{mg} \mathrm{L}^{-1}$ treatment (Table 2). Shoot dry weights increased with successive cuttings in all treatments (data not shown). An increase in greenhouse temperature occurred as spring approached and likely contributed to the increase in growth. The control had greater total growth, combined over three cuttings, than any As treatment. Growth showed a weak trend to decrease with increasing solution As concentration. Switchgrass had a low UR, 2.4 averaged over treatments and a low TF, 0.5.

\subsection{Plant Arsenic}

During the course of this study, several tanks failed and therefore data reported in Figure 1 represent only treatments common to all plant species $\left(0.0,0.75,3.75\right.$ and $\left.5.25 \mathrm{mg} \mathrm{As} \mathrm{L}^{-1}\right)$. Statistical groupings were adjusted accordingly. In this study As uptake patterns by plants could be separated into three groups: 1) sensitive plants that at low As concentrations had reduced growth (coreopsis and tithonia), plants that tolerated As in the growing medium by preventing its accumulation in tissue (iris), and plants that took-up As but could moderate As toxic effects (marigold, sunflower and switchgrass). The average concentration in control tanks was $0.0028 \mathrm{mg} \mathrm{As} \mathrm{L}^{-1}$ and coreopsis readily accumulated As at this low level. Both coreopsis and tithonia had maximum As

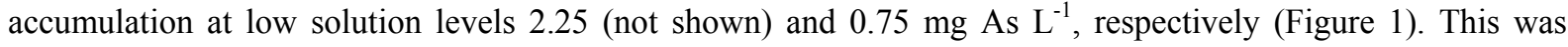
accompanied by a $65 \%$ reduction in dry weight for coreopsis and an $85 \%$ reduction for tithonia at maximum plant As levels (Table 2).

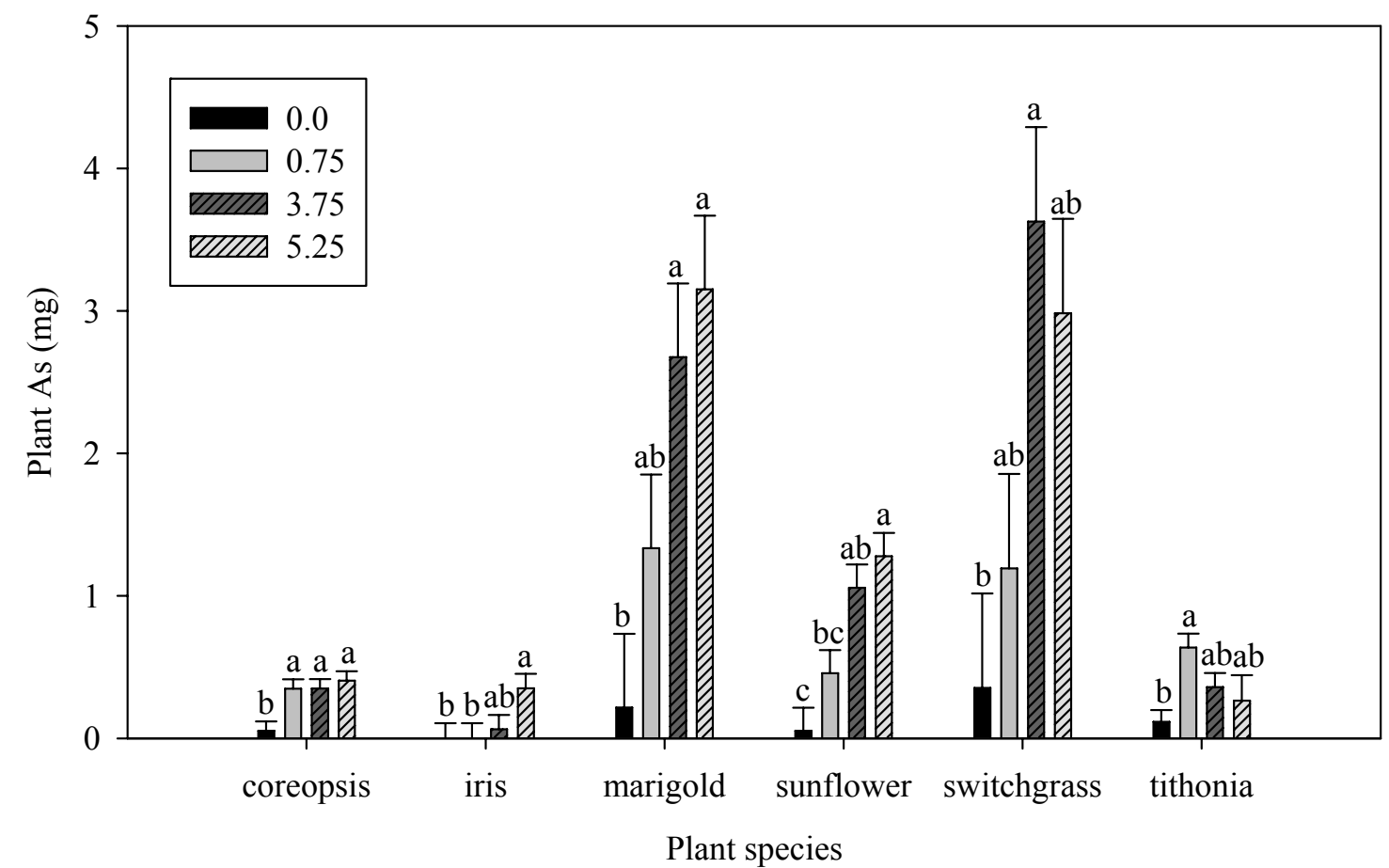

Figure 1. Whole plant arsenic content (mg) from plants grown in $0.0,0.75,3.75$, or $5.25 \mathrm{mg} \mathrm{As} \mathrm{L}^{-1}$ solution concentration 
Iris accumulated very little As in its tissue at solution levels up to $5 \mathrm{mg} \mathrm{As} \mathrm{L}^{-1}$ with no negative effects on growth (Figure 1). Maximum As accumulation in iris was above the high level used in this study. It is worth mentioning that as long as the rhizome remains healthy iris leaves can be removed and will be replaced by new growth. A portion of the rhizome remains above the surface and can be readily harvested increasing total As removal from soil.

Switchgrass had a maximum plant As content at $3.00 \mathrm{mg} \mathrm{L}^{-1}$ of $3.8 \mathrm{mg} \mathrm{As} \mathrm{kg}^{-1}$ dry weight, the highest amount removed by any species at any solution concentration. Switchgrass can be harvested multiple times throughout a growing season. Marigold and sunflower continued to accumulate As in plant tissue through the highest solution concentration used in this study with no significant effect on shoot or root dry weights (Table 2). The solution concentration where maximum As accumulation occurred was above the highest concentration used in the study. Given no apparent affects on plant dry weights these plants may remove As from soils considerably more contaminated.

\section{Discussion}

All plants used in this study were As non-hyperaccumulators, however, there were different patterns in As accumulation among the plant species. Only a small amount of As was found in iris root and shoot tissue. Based on reduction in dry weight, tithonia and coreopsis were most sensitive to As exposure and did not produce sufficient dry weight for remediation purposes. Iris and marigold dry weights at the $5.25 \mathrm{mg} \mathrm{L}^{-1}$ treatments increased over controls by 2.3 and $1.3 \mathrm{x}$, respectively. Similar increases in dry weight at low As concentrations were reported by Carbonell-Barrachina, Aarabi, DeLaune, Gambrell, and Patrick (1998) with Spartina patens and Spartina alterniflora, Shaibura and Kawai (2009) with Brassica rapa, Srivastava et al. (2007) with Hydrilla verticillata, Woolson et al. (1971) with maize, Marin et al. (1992) with rice and Jacobs, Keeney, and Walsh (1970) with peas, wheat and potatoes. Jacobs et al. (1970) attributed this to improved plant P status as a result of arsenate displacing phosphate from soil increasing P availability. However, in the present study plants were grown hydroponically and this mechanism would not be in effect. Improved mineral nutrition at low As concentration could account for the higher dry weights.

Phytoremediation of As usually requires phytoextraction and/or phytostabilization. Phytoextraction involves As uptake from soil by plant roots and subsequent transport from root to shoot tissue where it can be harvested. Phytostabilization requires production of enough plant biomass to prevent soil As movement from the contaminated site by erosion and As sequestration in plant roots to limit leaching. An appropriate candidate for phytoremediation should accumulate As at a rate equal to or greater than that found in the soil, i.e., it should have an uptake ratio (UR) $\geq 1$. In the present study coreopsis and tithonia had the highest UR but even at the lowest solution As concentration biomass production was too low for use in As removal or soil stabilization. Marigold and sunflower have UR values at $5.25 \mathrm{mg} \mathrm{L}^{-1}$ solution As concentration of 7.4 and 16.6, respectively. Their TFs (translocation factor) are near one, and at the high As rate both produce dry weights similar to their controls. Therefore, marigold and sunflower are appealing candidates for phytoremediation and phytostabilization. Switchgrass and iris are plants that can be harvested multiple times a year. This can partially offset the low UR and TF in switchgrass making it a candidate for phytostabilization. Iris has a UR of 6.7 and a TF of 9.2. The TF of iris and marigold continued to increase with increasing solution As up to the high rate used in this study. The maximum tissue As concentration for these species was not determined. Iris is an attractive candidates for phytostabilization and perhaps even phytoremediation. The fact that both marigold and iris produced flowers at all As rates may provide an added advantage in that cut flowers may provide small amounts of revenue to help offset the cost of remediation.

\section{References}

Ansari, M. K. A., Shao, H. B., Umar, S., Ahmad, A., Ansari, S. H., Iqbal, M., \& Owens, G. (2013). Screening Indian mustard genotypes for phytoremediating arsenic-contaminated soils. Clean Soil, Air, Water, 41, 195-201. http://dx.doi.org/10.1002/clen.201100752

Bleeker, P. M., Schat, H., Vooijs, R., Verkleij, J. A. C., \& Ernst, W. H. O. (2003). Mechanisms of arsenate $\begin{array}{llllll}\text { tolerance in Cytisus striatus. New } & \text { Phytologist, } & 157, & 33-38 .\end{array}$ http://dx.doi.org/10.1046/j.1469-8137.2003.00542.x

Caille, N., Zhao, F. J., \& McGrath, S. P. (2005). Comparison of root absorption, translocation and tolerance of arsenic in the hyperaccumulator Pteris vittata and the nonhyperaccumulator Pteris tremula. New Phytologist, 165, 755-761. http://dx.doi.org/10.1111/j.1469-8137.2004.01239.x 
Carbonell-Barrachina, A. A, Aarabi, M. A., DeLaune, R. D., Gambrell, R. P., \& Patrick, W. H. (1998). The influence of arsenic chemical form and concentration on Spartina patens and Spartina alterniflora growth and tissue arsenic concentration. Plant and Soil, 198, 33-43. http://dx.doi.org/10.1023/A:1004285625998

Castillo-Michel, H. A., Zuverza-Mena, N., Parsons, J. G., Dokken, K. M., Duarte-Gardea, M., Peralta-Videa, J. R., \& Gardea-Torresdey, J. L. (2009). Accumulation, speciation, and coordination of arsenic in an inbred line and a wild type cultivar of the desert plant species Chilopsis linearis (Desert willow). Phytochemistry, 70, 540-545. http://dx.doi.org/10.1016/j.phytochem.2009.01.010

Jacobs, L. W., Keeney, D. R., \& Walsh, L. M. (1970). Arsenic residue toxicity to vegetable crops grown on $\begin{array}{llll}\text { plainfield } \quad \text { sand. } & \text { Agronomy }\end{array}$ http://dx.doi.org/10.2134/agronj1970.00021962006200050011x

Kabata-Pendias, A., \& Pendias, H. (1992). Trace Elements in Soils and Plants. Boca Raton: CRC Press.

Karimi, N., Ghaderian, S. M., Raab, A., Feldmann, J., \& Meharg, A. A. (2009). An arsenic-accumulating, hypertolerant brassica, Isatis capadocica. New Phytologist, 184, 41-47. http://dx.doi.org/10.1111/j.1469-8137.2009.02982.x

Ma, L. Q., Komar, K. M., Tu, C., Zhang, W., Cai, Y., \& Kennelley, E. D. (2001). A fern that hyperaccumulates arsenic. Nature, 409, 579. http://dx.doi.org/10.1038/35054664

Machado-Estrada, B., Calderón, J., Moreno-Sánchez, R., \& Rodríguez-Zavala, J. S. (2012). Accumulation of arsenic, lead, copper, and zinc, and synthesis of phytochelatins by indigenous plants of a mining impacted area. Environmental Science and Pollution Research, Published online: 28 November 2012. http://dx.doi.org/10.1007/s11356-012-1344-8

Marin, A. R., Masscheleyn, P. H., \& Patrick, W. H. (1992). The influence of chemical form and concentration of arsenic on rice growth and tissue arsenic concentration. Plant and Soil, 139, 175-183. http://dx.doi.org/10.1007/BF00029094

McGrath, S. P., \& Zhao, F. J. (2003). Phytoextraction of metals and metalloids from contaminated soils. Current Opinion in Biotechnology, 14, 277-282. http://dx.doi.org/10.1016/S0958-1669(03)00060-0

Meharg, A. A. (1994). Integrated tolerance mechanisms - constitutive and adaptive plant- responses to elevated metal concentrations in the environment. Plant, Cell and Environment, 17, 989-993. http://dx.doi.org/10.1111/j.1365-3040.1994.tb02032.x

Meharg, A. A. (2003). Variation in arsenic accumulation-hyperaccumulation in ferns and their allies. New Phytologist, 157, 25-31.

Meharg, A. A., Naylor, J., \& Macnair, M. R. (1994). Phosphorus nutrition of arsenate-tolerant and nontolerant phenotypes of velvetgrass. Journal of Environmental Quality, 23, 234-238. http://dx.doi.org/10.2134/jeq1994.00472425002300020003x

Murphy, E. A., \& Aucott, M. (1998). An assessment of the amounts of arsenical pesticides used historically in a geographical area. Science of the Total Environment, 218, 89-101. http://dx.doi.org/10.1016/S0048-9697(98)00180-6

SAS Institute. (1999). SAS for Windows, SAS Inst., Cary, N.C.

Shaibur, M. R., \& Kawai, S. (2009). Effect of arsenic on visible symptom and arsenic concentration in hydroponic Japanese mustard spinach. Environmental and Experimental Botany, 67, 65-70. http://dx.doi.org/10.1016/j.envexpbot.2009.06.001

Singh, N., \& Ma, L. Q. (2006). Arsenic speciation, and arsenic and phosphate distribution in arsenic hyperaccumulator Pteris vittata L. and non-hyperaccumulator Pteris ensiformis L. Environmental Pollution, 141, 238-246. http://dx.doi.org/10.1016/j.envpol.2005.08.050

Srivastava, S., Mishra, S., Tripathi, R. D., Dwivedi, S., Trivedi, P. K., \& Tandon, P. K. (2007). Phytochelatins and antioxidant systems respond differentially during arsenite and arsenate stress in Hydrilla verticillata (L.f.) Royle. Environmental Science and Technology, 41, 2930-2936. http://pubs.acs.org/doi/abs/10.1021/es062167j

Visoottiviseth, P., Francesconi, K., \& Sridokchan, W. (2002). The potential of Thai indigenous plant species for the phytoremediation of arsenic contaminated land. Environmental Pollution, 118, 453-461. http://dx.doi.org/10.1016/S0269-7491(01)00293-7 
Walsh, L. M., Sumner, M. E., \& Keeney, D. R. (1977). Occurrence and distribution of arsenic in soils and plants. Environmental Health Perspective, 19, 67-71. Retrieved from http://www.ncbi.nlm.nih.gov/pmc/articles/PMC1637429/

Woolson, E. A., Axley, J. H., \& Kearney, P. C. (1971). Correlation between available soil arsenic, estimated by six methods, and response of corn (Zea mays L.). Soil Science Society of America Proceedings, 35, $101-105$. http://dx.doi.org/10.2136/sssaj1971.03615995003500010030x

Zhao, F. J., Dunham, S. J., \& McGrath, S. P. (2002). Arsenic hyperaccumulation by different fern species. New Phytologist, 156, 27-31. http://dx.doi.org/10.1046/j.1469-8137.2002.00493.x

Zhao, F. J., Ma, J. F., Meharg, A. A., \& McGrath, S. P. (2009). Arsenic uptake and metabolism in plants. New Phytologist, 181, 777-794. http://dx.doi.org/10.1111/j.1469-8137.2008.02716.x

\section{Copyrights}

Copyright for this article is retained by the author(s), with first publication rights granted to the journal.

This is an open-access article distributed under the terms and conditions of the Creative Commons Attribution license (http://creativecommons.org/licenses/by/3.0/). 